\title{
Towards More Effective Cooperation? The Role of States in Shaping NATO-EU Interaction and Cooperation
}

\section{Tinatin Aghniashvili}

Ministry of Defense of Georgia

\begin{abstract}
Effective cooperation between the European Union (EU) and North Atlantic Treaty Organization (NATO) is not only desirable, but rather mandatory in this interdependent and interlinked World. The contemporary multifaceted security threats and challenges have diminished the importance of the national borders and made the members of the institutions almost equally vulnerable. Due to the inherited similarities among organizations, the perception of burden sharing seems natural. However, the existing cooperation framework leaves a big room for improvement. The article explores the factors limiting effective cooperation between the organizations and the analysis is derived from studying individual states' (dual and non-dual members) behavior in shaping institutions' interaction. The paper analyzes the roles of the EU and NATO during the Libyan crisis in the neighborhood of Europe and their interaction in Afghanistan - beyond the Euro-Atlantic area. The findings of the analysis show that some of the non-dual members of the organization "hold institutions hostage ${ }^{\prime 1}$; fragmented positions of the dual members impede the elaboration of a holistic EU policy on crisis management (CSDP) and eventually, hamper formation of a joint EU-NATO strategic vision. Furthermore, lack of division of labor on the ground leads to overlapping of functions to certain extent and cooperation among institutions is better on operational rather than on the strategic level.
\end{abstract}

Keywords: NATO, European Union, security policy, Libya, NATO-EU Cooperation.

1 Jolyon Howorth, Security and Defence Policy in the European Union (London: Palgrave Macmillan, 2014), 130. 


\section{Introduction}

In the $21^{\text {st }}$ century the international system faces extremely dynamic, multifaceted and complex threats and challenges which require a comprehensive and holistic approach to be tackled. There are no purely military or civilian solutions to the challenges; combination and rational use of the existing capabilities by the institutions and states seems to be the only option leading to a more peaceful world.

Therefore, studying the interaction between two key institutions such as NATO and the EU in the interconnected world is crucial as they play the important role in the global security architecture. The article will mainly focus on analyzing relations among the EU's Common Security and Defence Policy (CSDP) and NATO.

There are inherited similarities between these two organizations which naturally push them towards cooperation and enhance perception of a burdensharing: both organizations share the so-called "Western Values" associated with the democratic norms and principles; face similar multidimensional security threats and challenges; exercise the comprehensive approach in the field of crisis management, conduct operations in the same countries throughout the world; are responsible for the European security and, most importantly, share twenty two members in common out of twenty eight states. ${ }^{2}$

The EU and NATO have undergone different phases of cooperation since the 1990s. The dynamic of relations show that their cooperation in early 2000 s was more fruitful than in the following years. In 2003 the Berlin Plus Agreement (allowing the EU to use NATO assets for crisis management operations) was finalized and translated into two successful operations in Balkans. ${ }^{3}$ Since then, institutional cooperation has not been enriched either within Berlin Plus Arrangement or beyond its framework.

In the official documents institutions portray their relations as a "strategic partnership" ${ }^{4}$; in reality NATO and the EU share common strategic interests but without common strategic agenda.

As Herman Van Rompuy, the former President of the European Council, stated, "the ability of our two organizations to shape our future security environment would be enormous if they worked together. It is time to break down the remaining walls between them." ${ }^{5}$ The paper will analyze why this "remain-

2 "Montenegro is in the process of joining NATO," accessed October, 11, 2016, http://www.nato.int/cps/en/natohq/topics_49736.htm.

3 “About CSDP-The Berlin Plus Agreement," accessed April 17, 2016, http://eeas.europa.eu/csdp/about-csdp/berlin/index_en.htm.

4 "Wales Summit Declaration, 5 September, 2014," accessed April 1, 2016, http://www.nato.int/cps/en/natohq/official_texts_112964.htm.

5 "Remarks by Herman Van Rompuy, President of the European Council," Lisbon Summit, 2010, accessed January 20, 2016, http://www.consilium.europa.eu/uedocs/ cms_data/docs/pressdata/en/ec/117890.pdf. 
ing walls" still exist and why organizations are not very successful in combining efforts to support international peace and stability in a rational, cost-effective and mutually beneficial way.

Consequently, the article will seek to answer the following question: What are the factors limiting an effective cooperation between the EU and NATO?

The NATO-EU relation is a complex phenomenon and therefore cannot be limited to the inter-institutional, bilateral format; multilateral dynamics orchestrated by the specific countries define their cooperation to the largest extent. Therefore, the EU-NATO interaction will be analyzed from the individual states' angle (dual and non-dual members) rather than from the institutions' perspective.

The article will investigate the following hypothesis: 1 . Some of the non-dual member countries hold "institutions hostage"; ${ }^{6} 2$. Divergent positions among dual members towards the EU's CSDP policy contribute to the lack of a NATO$\mathrm{EU}$ joint strategic vision. Under both conditions, effective cooperation of the institutions is undermined.

As it was mentioned, NATO and the EU share twenty two members in common and twelve states ${ }^{7}$ remain only on the one side of the institutional framework (see the Annex A). This asymmetric membership has different impact on NATO-EU relations: some of the non-dual members play more positive role (Canada, Sweden, Finland, Norway) while others contribute to the limited cooperation.

Due to the large number and complex interaction between the non-dual members, the research will concentrate on Turkey and Cyprus constantly and significantly affecting the organizations' relations due to their political dispute.

Within the non-dual members the role of the US is also remarkable, however as the US position towards EU's security and defense policy evolved throughout the years from skepticism towards necessary burden-sharing, it will not directly fall within the scope of the article.

The paper will also discuss the divergent positions' of the dual member states of the institutions and argue that European countries' reluctance to elaborate a holistic and coherent CSDP has its negative implication on the EUNATO collaboration. Division among the dual member countries between socalled "Atlanticist" ${ }^{8}$ and "Europeanist" lays out the solid ground for different foreign and security policy priorities.

The fragmented position of the European states within CSDP serves as the root cause of the challenge among institutions and necessary precondition for cooperation.

6 Howorth, Security and Defence Policy in the European Union, 130.

7 "Members of NATO and not EU," http://www.nato.int/cps/en/natolive/topics 52044.htm; http://europa.eu/about-eu/countries/member-countries/, accessed April 17, 2016.

8 Howorth, Security and Defence Policy in the European Union, 120. 
The article will analyze relations between the EU and NATO in Afghanistan and Libya, which are two totally different cases; nevertheless, they provide a comprehensive picture of the institutions' interaction on different levels, at different places and under different conditions.

The structure of the paper will be presented accordingly: firstly, the existing institutional framework of cooperation between the EU and NATO will be outlined; secondly, the role of Turkey and Cyprus will be discussed in shaping organizations' behavior; thirdly, relations among institutions in Afghanistan will be addressed and fourthly, the organizations' performance will be examined during the Libyan crisis, thus questioning the relevance of the Berlin Plus agreement.

\section{Methodology}

As it was noted, the article will limit itself to the analysis of the impact Turkey and Cyprus are having on NATO-CSDP relations due to the political dispute between the countries and the right of the so-called "veto power" they exercise within the institutions. Cyprus is the only country among the non-dual members of the EU, which is not part of the NATO "Partnership for Peace" program and thus does not have security agreement with the Alliance. ${ }^{9}$

The research will address relations among the EU and NATO in Afghanistan, beyond the Euro-Atlantic area, and during the Libyan crisis, in the immediate neighborhood of Europe.

\begin{tabular}{|c|c|}
\hline Libya & Afghanistan \\
\hline European neighborhood & Beyond Euro-Atlantic Area \\
\hline Threat to Europe & No direct threat \\
\hline Military Operation - initially & $\begin{array}{c}\text { Civilian Mission (EU) - Training Mis- } \\
\text { sion (NATO) }\end{array}$ \\
\hline Urgency & No Urgency \\
\hline None of them present & Both of them present \\
\hline
\end{tabular}

In the case of Afghanistan both organizations were simultaneously present in the theater of operation aimed at training Afghan Police Forces; carrying out non-combatant missions and as a precondition, NATO dominated the security environment. The urgency to establish the mission in Afghanistan was low compared to Libya.

9 Stephanie C. Hofmann, "Overlapping Institutions in the Realm of International Security: The Case of NATO and ESDP," Perspectives on Politics 7, no. 1 (March 2009): 4552, quote on p. 46. 
In the Libyan case the crisis took place at the doorstep of Europe making the EU vulnerable to the threat coming from the south. Besides, the sense of urgency existed: NATO, the EU and individual states felt the responsibility to undertake concrete measures in a timely manner; the EU was supposed to implement military operation after its high ambition and strengthened CSDP pillar, while initially NATO was reluctant to be engaged in Libya and finally, none of the organizations were on the ground before the crisis erupted.

These case studies lay out the solid basis for analyzing peculiarities of the institutions' defense and security postures and reveal inter-institutional challenges as well as deficiencies within the CSDP.

\section{Existing Cooperation Framework}

Two key millstones can be identified in NATO-CSDP development: Europe's quest to develop autonomy in security and defense dimension in 1998 and the signature of the Berlin Plus Agreement in 2002.

Initially, NATO and especially, the US were skeptical towards Saint-Malo Declaration (French-UK Summit, 1998) ${ }^{10}$ stating that "the Union must have the capacity for autonomous action, backed up by the credible military forces" and resulting in construction of a common European Security and Defence Policy (ESDP). ${ }^{11}$ The basic reason was the threat of duplication with the NATO assets resulting in potential competition.

Hereby, the UK's position is very interesting, as it was regarded to be the most "Atlanticist" ally among the dual members. The UK supported the development of the European "military arm" to keep an eye on the ESDP and make sure that its development would not contradict NATO's interests.

The US initial suspicious was translated into Secretary of State Madeline Albright's "3D" ${ }^{12}$ provisions giving a green light to the ESDP under certain conditions such as no decoupling, no duplication and no discrimination. In 2000 the US position was further reinforced by statement that "NATO remains their first choice when it comes to the military force."13

In the following years the US skepticism was replaced by high need of burden sharing and development of a strong European military capabilities reinforcing NATO rather than competing with it. ${ }^{14}$ Europe was pushed to take more responsibility for maintaining peace and security within its borders in order to relieve the US troops from Europe.

10 Joint Declaration issued at the British-French Summit, Saint Malo, France, December 3-4, 1998.

11 Jolyon Howorth and John T.S. Keeler, Defending Europe: The EU, NATO and the Quest for European Autonomy (New York: Palgrave Macmillan, 2003), 10.

12 Howorth, Security and Defence Policy in the European Union, 112.

13 Ibid., 113. Philip Gordon, Former Director for European Affairs at the National Security Council.

14 John Baylis and Jon Roper, The United States and Europe (New York: Routledge, 2006), 120. 
In parallel, NATO and the EU have been conducting operations and missions in various parts of the world. There are substantial differences in military (human resources, logistic) and operational (structural) capabilities of the organizations. This cannot be considered as undermining factor of cooperation, rather the opposite, as it creates the basis of burden sharing between them.

Unlike NATO, the EU lacks a permanent operational headquarters (HQ) to effectively execute military operations. Due to the fact that EU does not have a strategic planning capability embedded in Military Staff and a permanent headquarters, ${ }^{15}$ CSDP missions are organized from the ad-hoc HQs.

The only institutional framework of cooperation (on strategic level) between the organizations is the "Berlin Plus" Agreement ${ }^{16}$ of 2003 enabling the EU to use NATO assets and capabilities for the crisis management operation.

It took three years of complicated negotiations to conclude the agreement between organizations. One of the key reasons of the lingering rounds of consultations was the Turkish position, ${ }^{17}$ which feared that once asset-borrowing policy was agreed, the national security interests' near its borders would be jeopardized. Finally, Turkey allowed reaching agreement under specific circumstances: ${ }^{18}$ ESDP will not be used against NATO allies, Berlin Plus will refer only to dual members of the EU and NATO and parties of the "Partnership for Peace" having bilateral security agreement with the Alliance, Cyprus (and Malta) would not contribute to the operations under Berlin plus arrangements once it had become EU member. The Agreement was signed in December $2002^{19}$ and Cyprus became member of EU in May, $2004^{20}$ within the large round of enlargement.

Another reason for launching Berlin Plus Agreement was Turkey's high expectation on approaching the EU. In 2002 Greece softened its position towards Turkey's membership to the organization and the EU identified a timeframe as of December $2004^{21}$ to start accession talks with Turkey. The following years have clearly showed that these processes have not been very successful and the reasons behind the non-reactivation of the Berlin Plus can be linked to this fact as well.

Additional and most important factor paving a way towards agreement was the unified position of the European countries on threat perception coming from the Balkans, high need to undertake concrete measures and the US readi-

15 Ibid., 34.

16 Martin Reichard, The EU-NATO Relations: A Legal and Political Perspective (Aldershot, Burlington: Ashgate Publishing Company, 2006), 275.

17 Ibid., 287.

18 Ibid.

19 Reichard, The EU-NATO Relations: A Legal and Political Perspective, 275.

20 "EU member countries," accessed March 3, 2016, http://europa.eu/about-eu/ countries/member-countries/index_en.htm.

21 Reichard, The EU-NATO Relations: A Legal and Political Perspective, 287. 
ness to disengage from Europe and mobilize its troops for deployment to the East.

Since its inception two operations have been undertaken within the framework of the Berlin Plus Agreement: military operation (Concordia) in the Former Yugoslav Republic of Macedonia in $2003^{22}$ and second military operation (Althea) in Bosnia-Herzegovina since 2004, which is the only ongoing operation under the Berlin Plus umbrella.

On operational level, institutions have managed to establish more effective cooperation framework than on the strategic level. In 2005, NATO Permanent Liaison Team ${ }^{23}$ was established at the EU Military Staff and the EU Cell has been operational at SHAPE (NATO's strategic command for cooperation in Mons, Belgium) since 2006. Thus, the Berlin Plus Agreement provides a unique opportunity for the EU to utilize already existing structures of the Alliance for crisis management operations.

In the era of austerity, both organizations have realized the significance of sharing capabilities, but on intra-institutional and not inter-institutional level: NATO has elaborated the Smart Defence Initiative ${ }^{24}$ while the EU has developed a Pooling and Sharing Initiative. ${ }^{25}$ Hence, reluctance of the organizations to share resources eventually leads them to the acquisition of additional capabilities and to certain extent, overlapping of their functions.

Another crucial factor is the double responsibility of the dual member states within both organizations. They are obliged to contribute to NATO as well as the EU operations separately. The dual members sometimes have to make choices among organizations' activities resulting in the zero-sum contributions and "in a world of shrinking resources, everybody recognizes European forces and capacity, whether deployed via NATO or via CSDP, are all drawn from the same pool." 26

Hence, existing NATO-EU legal cooperation framework allows organizations to share their capabilities and conduct successful operations, if the political will is present.

\footnotetext{
22 “Mission Description," accessed March 3, 2016, www.eeas.europa.eu/archives/ csdp/missions-and-operations/concordia/mission-description/index_en.htm.

23 "NATO-EU: Strategic Partnership, Framework for Cooperation," accessed February 26, 2016, http://www.nato.int/cps/en/natohq/topics_49217.htm.

24 "Smart Defence," accessed January 9, 2016, http://www.nato.int/cps/en/natohq/ topics_84268.htm.

25 "EDA's Pooling and Sharing," accessed January 9, 2016, https://www.eda.europa.eu/ docs/default-source/eda-factsheets/final-p-s_30012013_factsheet_cs5_gris.

26 Howorth, Security and Defence Policy in the European Union, 141.
} 


\section{The Role of the Non-dual Members in Shaping Institutions' Interaction}

\section{Turkey and Cyprus}

The political dispute between Turkey and Cyprus is a clear demonstration of how individual non-dual states can have a big impact on institutions' relations. Unresolved problems between Turkey and Greece over Aegean airspace, territorial waters and the divided island of Cyprus ${ }^{27}$ are the root causes of the tense relations between the countries.

The asymmetric memberships of Turkey (member of NATO and not the EU) and Cyprus (member of EU and not NATO) and the right of "veto power" (within CSDP and NATO) are the key factors contributing to the limited cooperation among institutions. As the French representative to NATO's Supreme Headquarters Allied Powers Europe (SHAPE) noted, relations between the EU and NATO resemble a "cat and mouse game," in which both of them blame each other and in the end of the day they have to interact "somehow." 28

Turkey's initial skepticism towards CSDP paved a way towards more complicated relations with the EU after the accession of Cyprus in $2004 .{ }^{29}$ Turkey became concerned about EU military capability development due to two main reasons: threat of being excluded from the European security architecture; especially, having a little impact on designing stability of its immediate neighborhood, deprived of the right to participate in the decision making process of the Political and Security Committee (PSC) unlike its important role in the Western European Union (WEU), and EU's reluctance to consider Turkey's accession.

Once Cyprus became the member of the EU, the "veto game" was launched between the countries resulting in limiting the possible areas of cooperation among organizations. ${ }^{30}$

Due to the Cypriot veto, Turkey faced obstacles to participate or being consulted on CSDP missions, which was the case before under the umbrella of ESDP: Turkey was the third contributor to the operation "Althea" in BosniaHerzegovina and even expressed its readiness to participate in the EU Battle Groups; ${ }^{31}$ Cyprus blocked Turkey's involvement in the European Defence Agency (EDA) ${ }^{32}$ The EU refused to sign agreement with Turkey on exchange of

27 Ibid., 131.

28 French Representative to Supreme Headquarters Allied Powers Europe. Interviewed by the author Tinatin Aghniashvili, Geneva, Switzerland, March 2016.

29 Richard Whitman and Stefan Wolff, The European Union as a Global Conflict Manager (New York: Routledge, 2012), 53.

30 Belgium Representative to NATO HQ. Interviewed by the author Tinatin Aghniashvili, Geneva, Switzerland, March, 2016.

31 Adam Szymanski and Marcin Terlikowski, "The Policy of Turkey towards EU-NATO Cooperation" (Warsaw: The Polish Institute of International Affairs, 2010).

32 Howorth, Security and Defence Policy in European Union, 132. 
classified information. Moreover, Turkey's aspiration to join the EU was hampered by Cyprus. ${ }^{33}$

On its side, Turkey banned the sharing of NATO's intelligence information to the EU, limited attempts to discuss the issues beyond the Berlin Plus Agreement and formal or informal engagement of Cyprus in EU-NATO cooperation. ${ }^{34}$

Throughout the years high level decision makers from both sides of the EU and NATO have been dedicating their efforts to overcome "veto policy," but all rounds of negotiations have failed. ${ }^{35}$ In 2010, NATO Secretary General proposed the EU-Turkey agreement to break the deadlock between institutions ${ }^{36}$ which envisaged exchange of the classified information, Turkish participation in EDA and Cyprus participation in both organizations' activities on a technical level. However, the rounds of consultations have failed.

Turkey has been extensively supported by the US representing a key power within the NATO framework. Turkey's strategic importance has been significantly increased for the US after the terrorist attack on September 11, 2001 followed by the military operation in Afghanistan. ${ }^{37}$ The Muslim country's engagement in the anti-terrorist coalition has been highly appreciated; however, the US does not have direct influence on EU's decisions.

Based on this analysis, it can be concluded that Turkey and Cyprus are influencing cooperation between the EU and NATO, and as the first hypothesis of the article states, are "holding the institutions hostage." 38

However, the challenges of the EU-NATO strategic cooperation cannot be limited only to Turkey and Cyprus exercising their "veto power." The picture is much more complex and comprehensive and is derived from the divergent positions of the dual member states.

\section{Police Training in Afghanistan}

Afghanistan provides an interesting venue where the relationship of the $\mathrm{EU}$ and NATO is worth observing due to a couple of reasons: both organizations were engaged beyond transatlantic area, simultaneously performing their duties; having a long term commitment towards Afghanistan and in need of each others' capabilities for successful accomplishment of the assigned objectives.

33 Kashmeri, The North Atlantic Treaty Organization and the European Union's Common Security and Defense Policy: Intersecting Trajectories, 33.

34 Münevver Cebeci, "NATO-EU Cooperation and Turkey," Turkish Policy Quarterly 10, no. 3 (2011): 93-103, 100, accessed March 11, 2016, http://turkishpolicy.com/pdf/ vol_10-no_3-cebeci.pdf.

35 Representative to the NATO International Staff. Interviewed by the author Tinatin Aghniashvili, Geneva, Switzerland, March 2016.

36 Szymanski and Terlikowski, "The Policy of Turkey towards EU-NATO Cooperation," 2010.

37 Howorth and Keeler, Defending Europe: The EU, NATO and the Quest for European Autonomy, 113.

38 Howorth, Security and Defence Policy in the European Union, 130. 
Hence, Afghanistan offered a unique opportunity for enhanced cooperation, as well as a venue to reveal the deficiencies between the institutions on the strategic, operational and tactical levels.

The case study specifically concentrates on the interaction between the EU and NATO in Afghanistan throughout 2007-2014, when both institutions have been involved in the training of the Afghan National Police (ANP) along with the other duties on the ground. Since 2007, the EU has been running the civilian Police Mission (EUPOL) in Afghanistan under the CSDP framework. ${ }^{39}$ The mandate of the mission has been extended until December $2016 .{ }^{40}$

In parallel, NATO has been conducting the Training Mission in Afghanistan (NTM-A) ${ }^{41}$ during 2009-2014, with a primary focus on training recruits and building the institutional training capacity of the Afghan Security Forces (Afghan National Army and Afghan National Police (ANP)).

The large number of ANP (by the end of 2014, ANP reached the strength of around 153,000$)^{42}$ clearly demonstrated the need for burden sharing among organizations and the importance of a holistic approach.

\section{Overcrowded International Presence and Poor Coordination}

Due to the fact that one of the highest priorities of the Afghan government is the development of the professional police forces, the international community has been very active in providing support in this domain within bilateral as well as multilateral formats.

Over 13 years, more than 37 international donors (states and organizations) were engaged to assist Afghan Police reform, most of them contributing to the EUPOL, NTM-A, or both. ${ }^{43}$ The UN, the EU, NATO, the US and Germany can be identified among key actors simultaneously performing their duties. Germany took leadership of assisting the Afghan Police forces after the UN Conference in 2002 on Security Sector Reform of Afghanistan. ${ }^{44}$ Even more, in 2007 the International Police Coordination Board was established to facilitate effective coordination of the foreign contributions, but with a little progress. ${ }^{45}$

39 "What is EUPOL Afghanistan," accessed March 1, 2016, http://www.eupol-afg.eu/ node/37.

40 Ibid.

41 "NATO and Afghanistan," accessed March 1, 2016, http://www.nato.int/cps/en/ natohq/topics_8189.htm.

43 European Court of Auditors, "The EU Police Mission in Afghanistan: Mixed Results," Special Report no. 7 (Luxembourg: Publications Office of the European Union, 2015), 19, accessed March 1, 2016, http://www.eca.europa.eu/Lists/ECADocuments/SR15_ 07/SR_EUPOL_AFGHANISTAN_EN.pdf.

44 Eva Gross and Ana E. Juncos, EU Conflict Prevention and Crisis Management: Roles, Institutions, and Policies (New York: Routledge, 2011), 121.

45 European Court of Auditors, "The EU Police Mission in Afghanistan," 19. 
Along with the multiplicity of the actors, there was a lack of leadership and insufficient coordination to synchronize the donors' assistance. Due to the absence of coherent policy in this multidimensional environment, implementation of the Afghan police reform became very complicated, thus resulting in introduction of different types of trainings (in some cases contradictory and less effective) ${ }^{46}$ by various donors.

Hence, on one hand the multiplicity of the donors on the ground can be regarded as advantage, but on the other - in the absence of a coordinated mechanism and a tough security environment, it can become even more challenging for the host government and might lead to the irrational use of the external resources.

\section{Internal and External Challenges of EUPOL}

The EU's engagement in the overcrowded international landscape of Afghanistan has been marked with uncertainty from the initial phase. Establishment of the EUPOL was largely defined by German pressure (as a leading nation) to strengthen police reform under the EU umbrella as well as the US willingness for the burden sharing. ${ }^{47}$

The challenges of the EUPOL mission in Afghanistan can be summarized accordingly: lack of human resources, logistic capabilities and a clear guidance, insufficient funding, incoherence among the EU institutions, preferences of the EU member states to contribute to other missions, small contributions depriving from the right to undertake a coordination function, tough security environment, high level of illiteracy of the Afghan police forces and a lack of strategic agreement with NATO responsible for maintaining security on the ground.

Although the Council made a decision to launch the EUPOL, the EU members showed reluctance to contribute to the mission. Two months after the Council's decision, the EUPOL had only four staff officers operating in Kabul. ${ }^{48}$ The deployment process lingered and it has never reached the threshold of required human resources: The initial plan of deploying 200 experts has not been achieved until 2009 (after two years) and when in 2008 the Council decided to double the staff to 400 , the maximum number of the experts reached 350 in $2012 .{ }^{49}$ Even though the number of the EU member states engaged in EUPOL has been gradually increased over the years, ${ }^{50}$ the size of their contributions remained very small and therefore did not have a big impact on the successful execution of the mission's objectives. Important factor is that Canada and Nor-

46 Whitman and Wolff, The European Union as a Global Conflict Manager, 112.

47 Panos Koutrakos, The EU Common Security and Defense Policy (Oxford: Oxford University Press, 2013), 147.

48 European Court of Auditors, "The EU Police Mission in Afghanistan," 15.

49 Ibid., 16.

5019 EU states in 2009, 22 states in 2010, 23 states in 2012. See House of Lords, "The EU's Afghan Police Mission," London, 2011; "EUPOL Afghanistan, Factsheet," accessed April 22, 2016, http://moi.gov.af/Content/files/eupol-eng-factsheet.pdf. 


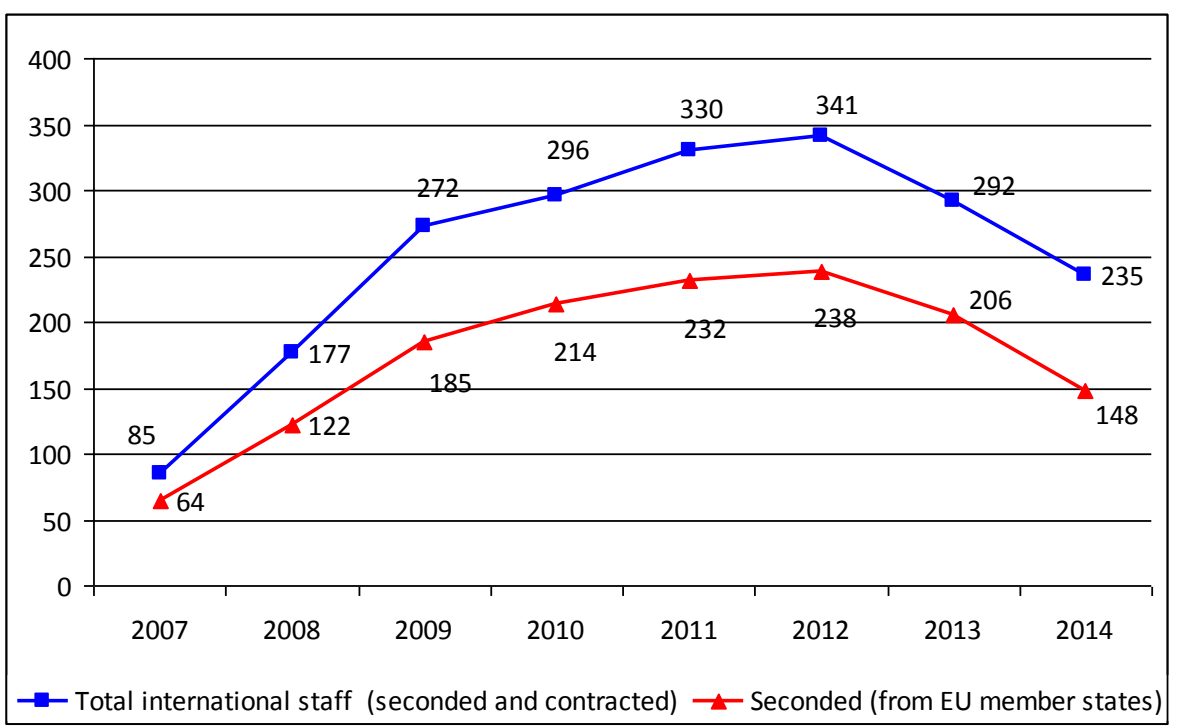

Source: EEAS (CPCC).

Figure 1: Total international (seconded and contracted) and EU seconded staff in EUPOL on 31 December of each year from 2007 to 2014.

way (members of NATO and not EU) have also contributed to the EUPOL ${ }^{51}$ and demonstrated that non-dual members can be reliable partners as well.

The EUPOL was not very successful in recruiting seconded personnel due to the competition with other CSDP missions, NTM-A and the UN missions. ${ }^{52}$

Moreover, leadership and logistic problems further affected the credibility of the mission. During the first 18 months the head of the mission has changed three times. ${ }^{53}$

Another obstacle was lack of a clear guidance from Brussels on EUPOL's mission and functions. Mandate has been regularly adjusted to the changing priorities and situation on the ground. ${ }^{54}$ This fact demonstrated the shortfalls in a common and coherent policy of the CSDP civilian mission in Afghanistan.

Moreover, EUPOL revealed the institutional challenges and insufficient coordination among the EU bodies operating within Afghanistan and beyond its borders. Lack of funds for the mission can be attributed to the weak interaction between the EUPOL and the European Commission, which is responsible for fund raising. 55

51 Ibid.

52 European Court of Auditors, "The EU Police Mission in Afghanistan," 17.

53 Ibid., 5.

54 Ibid., 8.

55 Koutrakos, The EU Common Security and Defense Policy, 148. 
One of the additional objectives of the EUPOL was coordination of the international efforts contributing to the Afghan police reform. ${ }^{56}$ EUPOL was not able to accomplish this goal and bring together all European actors under a single framework, ${ }^{57}$ even though it has contributed to enhancing cooperation among EU members on the ground.

Another important obstacle for EUPOL was the fact that many EU member countries continued their preferred activities in Afghanistan within the bilateral format. ${ }^{58}$ Concrete states wanted to maintain their influence in specific directions as individual nations and not as the members of the organizations.

Shortcomings of the EUPOL mission can be attributed not only to internal, but external factors as well: challenging security environment on the ground, ineffective coordination among international donors and high level of illiteracy among the Afghan Police Forces (up to $80 \%)^{59}$ limited successful accomplishment of the assigned objectives.

However, the overall role of the EUPOL in Afghanistan should not be underestimated. The EUPOL managed to achieve concrete results. According to the European Court of Auditors, ${ }^{60}$ EUPOL has been partially effective in delivering its mandate: mission has been more successful in training related activities and less in mentoring and advising. Once the shortfalls have been identified, the EU was tasked to produce detailed guidance for CSDP missions. Progress has been made in creating conceptual base for the Ministry of Interior, developing training courses and establishing the Police Staff College as a key training facility. ${ }^{61}$ By the end of 2014, EUPOL has conducted 1,400 training courses for 31,000 trainees. ${ }^{62}$

Hence, launching a CSDP civilian mission in Afghanistan was a political decision initiated by an individual European country - Germany. Supremacy of the individual countries interests over institutions' objectives has been clearly demonstrated in Afghanistan.

\section{NATO-EU Interaction - Complex Mosaic}

The NATO-EU relation in Afghanistan resembles a complex mosaic with variable attitudes. Relation among institutions, especially in the prism of the Afghan Police training, has been launched on a positive note. The Alliance pushed the EU to contribute to the development of Afghanistan and paved the way to the establishment of the EUPOL mission in $2007 .^{63}$

56 Ibid.

57 European Court of Auditors, "The EU Police Mission in Afghanistan," 8.

58 Ibid., 18.

59 Ibid., 15.

60 Ibid., 7.

61 Ibid., 23.

62 Ibid., 24.

63 Flanagan Stephen, T.J. Cipoletti, and Amanda Tuninetti, "Afghanistan: A Stress Test for Transatlantic Security Cooperation," in The Transatlantic Relationship and EU- 
While conducting the largest and most challenging operation throughout its history - the International Security Assistance Force (ISAF), the Alliance realized the further need of the civilian capabilities. The aim of the Alliance's first "out of area" operation was to ensure security and assist the Government of Afghanistan in building up professional Afghan Security Forces. ${ }^{64}$ The large number of military troops deployed on the ground could not have guaranteed success of the operation due to multidimensional nature of the security challenges. Cooperation with civil society, implementation of the economic projects, the civilian reconstruction and, most importantly, the training of the Afghan police forces necessitated the enhanced cooperation with the EU.

The need of burden sharing beyond the Euro-Atlantic area became visible and both institutions, on political level, realized the importance of contributing the assets in which they exercised their comparative advantages.

However, the relations among the organizations in the theater of operation clearly revealed the existing shortfalls, which can be attributed to the lack of joint strategic vision, absence of technical agreements and division of labor. These obstacles laid out the solid ground towards duplicating the functions and in the end resulted in providing different kind of police training to the Afghan government.

Once activated, EUPOL had to cooperate with NATO as a key provider of the security in Afghanistan. Apart from the Berlin Plus Agreement (which was not referred to in case of Afghanistan as EUPOL is a civilian mission and not military operation), there was no formal agreement between the institutions facilitating successful cooperation for mutual needs.

Insufficient cooperation on the strategic level had its effect on the operational and tactical levels. Afghanistan has not been on the agenda of meetings between PSC and the NAC. ${ }^{65}$ And this resulted in the absence of joint strategic agenda.

There was significant difference in the size of EUPOL and NTM-A. The EUPOL was a small mission unable to set or impact the strategic agenda on police training while NTM-A represented a larger scale mission with the ambition of training Afghan Security Forces. The NTM-A aimed at bringing Afghan Army and police training under one single umbrella ${ }^{66}$ and was more focused on building the so-called "counter insurgency forces."

EUPOL was concentrated more on the civilian policing, while NTM-A was oriented on building more "military type" police forces claiming that it was more suitable for the existing environment in Afghanistan. These different ap-

U.S. Cooperation in Security, Report (CSIS, May 2011), accessed March 11, 2016, https://csis-prod.s3.amazonaws.com/s3fs-public/legacy_files/files/publication/

110501_Flanagan_EUUSSecurity_Issue\%204.pdf, 193.

64 "NATO and Afghanistan."

65 Whitman and Wolff, The European Union as a Global Conflict Manager, 113.

66 "NATO Training Mission." 
proaches resulted in a contradictory advice/training provided to the Ministry of Interior and could have been avoided if a joint strategic vision existed.

On the operational level, the need and willingness for cooperation among the EUPOL and NATO was more visible. The EUPOL staff once deployed in Kabul, ${ }^{67}$ regional commands and the provinces, needed protection on the ground, which was provided by NATO.

Deployments in the Provincial Reconstruction Teams (PRT) run by NATO have been suspended due to the absence of formal agreements between institutions. Therefore, the only solution was to initiate technical agreements with the individual lead (framework) nations resulting in a time consuming process. Besides, Turkey did not sign technical agreement with the EUPOL and consequently, the EU staff was not presented in the provinces controlled by Turkey. ${ }^{68}$

Moreover, due to the lack of the EU agreement with NATO on sharing classified information, the EUPOL's situational awareness and operations in a dangerous operating environment was restricted. ${ }^{69}$ Therefore, a lack of strategic agenda not only hampered cooperation between organizations, but impeded the execution of the EUPOL mandate to a certain extent.

To conclude, the analysis of the interaction between the EU and NATO in Afghanistan revealed a couple of important challenges and findings. Obstacles among the organizations can be attributed to the lack of a joint strategic agenda, technical agreements and sharing of classified information; moreover, the challenges of the EUPOL mission demonstrated the divergent positions of the European countries and revealed the deficiencies of the CSDP as an individual instrument. The lack of division of labor between the EU and NATO has led to the overlap of functions on the ground and resulted in providing contradictory training to the Afghan Government.

Overall, the cooperation between the EU and NATO beyond the Euro-Atlantic area, with less urgent precondition and non-military dimension (Police training) was not very successful. NATO was dominant in relations and shaped the interaction accordingly. However, it is of utmost importance to underline, that cooperation on the operational level was more effective and efficient than on the strategic level. Within the existing formal constrains organizations still cooperated at the maximum possible extent and managed to deliver the concrete result such as "agreement to jointly establish Professional Training Board responsible for the development and accreditation of police training curricula." ${ }^{70}$

Hence, the results derived from the Afghan case analysis underline different positions of the dual members (within EU) and a lack of common strategic vi-

67 Whitman and Wolff, The European Union as a Global Conflict Manager, 116.

68 European Court of Auditors, "The EU Police Mission in Afghanistan," 17.

69 Flanagan, Cipoletti, and Tuninetti, "Afghanistan: A Stress Test for Transatlantic Security Cooperation," 193.

70 European Court of Auditors, "The EU Police Mission in Afghanistan," 19. 
sion, which contributes to the reduced effectiveness of cooperation among organizations.

\section{The Libyan Crisis}

This section is dedicated to a study on the performance of the EU and NATO in the Libyan crisis, discussing the reasons behind the limited inter-institutional cooperation, as well as the challenges within the CSDP. Thus it reveals the preferences of the national interests over institutional needs.

As the French representative to SHAPE noted, NATO's operation in Libya has been characterized as the "Berlin Plus operation with the capabilities of the Alliance, with the European states' participation, but without the EU label." ${ }^{71}$

Hence, during the crisis in Libya the expectations and need of burden sharing between the EU and NATO under the existing legal framework such as the Berlin Plus have been very high. However, the Agreement has not been activated due to the divergent positions of the European countries, which underlines the relevance of the research paper's hypothesis. The EU has to officially submit request to NATO on implementation of the Berlin plus, but this did not happen in the case of Libya.

The Libyan crisis took place at the doorstep of Europe making the EU vulnerable to the threat coming from the south. Besides, the sense of urgency was obvious - NATO, the EU and individual states felt the responsibility to undertake concrete actions in a timely manner. In sum, four operations were designed during the Libyan crisis and three of them activated: Operation Odyssey Dawn led by the coalition forces, NATO's Operation Unified Protector and EU civilian mission EUBAM Libya came into force and the EU military Operation EUFOR Libya was left behind the scene.

In order to understand the complexity of the crisis, it is important to cast a glance at the positions of the foreign actors, whether states or institutions.

The operation in Libya was mandated by the UN and supported by regional organizations, therefore events developed rapidly. The Libyan crisis was "one of the pieces of the broader puzzle of the Arab Spring." ${ }^{72}$ After rebellion movements took place against Muammar Qaddafi regime ${ }^{73}$ in 2011, the Arab League issued a resolution ${ }^{74}$ calling on the UN Security Council (UNSC) to undertake all necessary measures and impose a non-fly zone. After the outbreak of the rev-

71 French Representative to Supreme Headquarters Allied Powers Europe. Interviewed by the author Tinatin Aghniashvili, Geneva, Switzerland, March 2016.

72 Maxime H.A. Larivé, Debating European Security and Defense Policy: Understanding the Complexity (Farnham, Burlington: Ashgate Publishing Company, 2014), 209.

73 Ibid.

74 Joel Peters, ed., The European Union and the Arab Spring: Promoting Democracy and Human Rights in the Middle East (Lanham, MD: Lexington Books, 2012), 40. 
olution and the death of 2000 civilians, $^{75}$ on March 17 UNSC issued the resolution on establishing a "no fly zone" over Libya and authorized the use of all necessary means to protect civilians. ${ }^{76}$

European countries, such as UK and France were the first ones to initiate implementation of the UN resolutions. On March 19, Operation Odyssey Dawn ${ }^{77}$ was launched under the supervision of the US and supported by the European countries. Hence, it showed the political will and readiness of France and UK to take responsibility in maintaining peace and security in their neighborhood. Despite the fact that UK is regarded to be more "Atlanticist" ally and France "Europeanist," their positions were united. However, this was not sufficient precondition for the whole EU to come up with a unified and holistic position with regard to the Libyan crisis.

The US treated the crisis in Northern Africa with a very careful attitude trying to obtain a legal mandate on the actions undertaken. It did not qualify the operation conducted in Libya as war. ${ }^{78}$ Decisive was the country's position to involve NATO and lead a coalition of the willing. However, in the case of Libya, many critics argued that the US was "leading from behind." 79

\section{The Libyan Crisis and NATO}

Three key reasons can be identified to understand NATO's engagement in the Libyan crisis, which was not on its security agenda: most importantly, the US pushed the involvement of the Alliance for political reasons (once it has been already engaged); from the operational point of view, NATO assets were needed and on the strategic level, the EU showed clear reluctance to be engaged.

It is important to outline, that NATO for the first time throughout its existence launched an operation against an Arab country. Contrary to the EU, Africa has never been in the orbit of NATO's vital interest. Throughout its long history the Alliance has a very poor record of being involved in African continent.

Despite this fact, on March 31, 2011 NATO officially took control over the military operation in Libya under the UN resolutions and launched the Operation Unified Protector (OUP) with the aim to implement an arms embargo, a

75 Florence Gaub, The North Atlantic Treaty Organization and Libya: Reviewing Operation Unified Protector (Carlisle, PA: Strategic Studies Institute and U.S. Army War College Press, 2013), 2.

76 Security Council Resolution 1973 (2011) on Libya, accessed April 3, 2016; http://www.nato.int/nato_static/assets/pdf/pdf_2011_03/20110927_110311-UNSCR-1973.pdf.

77 Joe Quartararo, Sr., Michael Rovenolt, and Randy White, "Libya's Operation Odyssey Dawn: Command and Control," Prism 3, no. 2, accessed April 2, 2016, https://www.ciaonet.org/attachments/20162/uploads.

78 Gaub, The North Atlantic Treaty Organization and Libya, 4.

79 Patricia A. Weitsman, Waging War, Alliances, Coalitions and Institutions of Interstate Violence (Stanford: Stanford University Press, 2014), 177. 
no-fly zone and protect civilians from attack or threat of attack. ${ }^{80}$ Within the frames of OUP, 2/3 of the strike sorties were carried out by France and UK and the rest by Italy, Canada, Denmark, Norway, Sweden and Belgium. ${ }^{81}$ The regional actors were also involved in the operation, but to a limited extent: the United Arab Emirates, Jordan and Qatar ${ }^{82}$ mostly remained in a supportive role. During the operation only air and naval capabilities of the Alliance and individual member states were used and OUP was officially ended in October 31, $2011 .^{83}$

The OUP achieved its mission defined by the UN without casualties and therefore was characterized as a successful operation. The OUP mandate did not envisage regime change in Libya and NATO's involvement in post-conflict reconstruction efforts. From a legal perspective, the UN's resolutions and notion of "Responsibility to Protect" (which has been first invoked by a unanimous UNSC vote) ${ }^{84}$ legitimized the Alliance's engagement in Libya.

The operation's immediate goals were reached in short term, but in medium and long run Libya went far from establishing peace and security. The regime of Colonel Qaddafi had been toppled, militias took over the responsibility of maintaining security, and instability grew by the day. ${ }^{85}$ Many critics described NATO's engagement in Libya as "war of choice" rather than "war of necessity." 86

\section{EU and Libya}

After implementation of a non-fly zone by NATO, the EU felt that it was supposed to "somehow" contribute to the stabilization of the crisis on its doorsteps and demonstrate unity of Europe. The EU-designed military operation was followed by the civilian mission in Libya, but with little success.

In April 2011, the European Council made a decision to launch a military operation EUFOR Libya aimed at supporting humanitarian operations in Libya. ${ }^{87}$ However, the EUFOR could be activated only based on the request of the UN Office for the Coordination of Humanitarian Affairs, ${ }^{88}$ which had never been considered, due to the security reasons on the ground. Cancellation of the

80 NATO, "Operation Unified Protector: Final Mission Stats," accessed April 12, 2016, http://www.nato.int/nato_static_fl2014/assets/pdf/pdf_2011_11/20111108_

111107-factsheet_up_factsfigures_en.pdf.

81 Gaub, The North Atlantic Treaty Organization and Libya, 7.

82 Ibid.

83 NATO, "Operation UNIFIED PROTECTOR: Final Mission Stats."

${ }^{84}$ Weitsman, Waging War: Alliances, Coalitions and Institutions of Interstate Violence, 184.

85 Gaub, The North Atlantic Treaty Organization and Libya, 28.

86 Ibid., 3.

87 “EUFOR Libya," accessed March 3, 2016, http://eeas.europa.eu/archives/csdp/ missions-and-operations/eufor-libya/index_en.htm.

88 Larivé, Debating European Security and Defense Policy, 209. 
EUFOR largely undermined the credibility of CSDP to lead and conduct an effective military operation in its neighborhood.

After two years, EU attempts still continued and in 2013 resulted in designing a new civilian mission EUBAM Libya ${ }^{89}$ - Integrated Border Assistance Mission under the auspices of the CSDP. The headquarters of the mission was in Tripoli but due to the deteriorating security conditions, since August 2014 the EUBAM has been operating from Tunisia with a very limited capacity. ${ }^{90}$

The EU and especially CSDP have been largely criticized for the failure to respond to the Libyan crisis in a timely and adequate manner. The high expectations on the EU's engagement in Libya were derived from the internal and external factors: special attribution of the EU towards Africa, the increased ambition of CSDP after Lisbon and the existence of the Berlin Plus Arrangement as a legal tool for a division of labor between the EU and NATO. From an external point of view, the legal tools (UN Resolutions), support from the regional organizations (Arab League) and the US unwillingness to lead the operations, were present.

After the inception of the CSDP, the EU has been very active on the African continent. Of the seventeen ${ }^{91}$ ongoing missions nine are conducted in Africa. EU has already implemented fifteen missions out of which eight operations (civilian and military) were carried out on the African continent. ${ }^{92}$ Execution of the majority CSDP operations in Africa is a crystal demonstration of EU's special attitude towards this continent. Moreover, this statistics highlights the EU's capacity to effectively undertake military operations when political will is present and contribute civilian assets to the peace-building and peacemaking process of the countries in need.

Another important factor is the credibility of CSDP. Since the Lisbon Treaty came into force in $2009,{ }^{93}$ the Libyan crisis was the biggest threat in the backyard of Europe. The treaty aimed at further strengthening the EU's foreign and security capabilities. Despite the increased quest and ambition of EU, after two years it turned out to be less capable to contribute to the peace making process, provide appropriate military assistance and consolidate the positions of the member countries when needed.

The third important factor is the existence of the Berlin Plus Arrangement. If the EU lacked the capabilities to undertake a military operation in Libya, it could have pushed for activation of the burden sharing tool with NATO. But a request has not been formally made by the EU side. The root cause of the

89 "EU Border Assistance Mission (EUBAM) in Libya," accessed March 3, 2016, http://eeas.europa.eu/csdp/missions-and-operations/eubam-libya/index_en.htm.

90 Ibid.

91 "Ongoing Missions and Operations."

92 Ibid.

93 European Union, Treaty of Lisbon, 2007, accessed March 3, 2016, http://eurlex.europa.eu/legal-content/EN/TXT/?uri=uriserv\%3Aai0033. 
challenge lies in the divergent positions among the European countries towards the CSDP. The perfect example is the German policy in this regard.

From the initial planning stage, Germany was against any kind of military operation in Libya and had abstained from the UNSC vote on the Libyan resolution, along with Russia and China. ${ }^{94}$ Economic factors were crucial in defining the country's political position. In 2009 Germany represented one of the major markets for the Libyan export; ${ }^{95}$ besides, the majority of the business contracts were negotiated with Gaddafi family. Therefore, Germany was skeptical to participate in the military campaign against Libya and the decision was backed up by the public. ${ }^{96}$

Meanwhile other European states such as UK and France were the ones who pushed for initiation of the first military operation in Libya due to political and security reasons. Unlike Germany, they were less concerned of the economic cooperation with Libya. Interesting is the position of Italy, which initially refused to impose sanctions against Libya due to its trade relations and business contracts, but later on "reluctantly joined France and the UK once a military operation was seen as unavoidable." ${ }^{\prime 7}$

These different approaches towards EU's security policy clearly undermine the credibility of CSDP and reveal a couple of important shortfalls: incoherence of European institutions, lack of capabilities and primacy of the national interest over the institution's objectives derived from the divergent positions among European states.

Overall, the EU and NATO cooperation in Libya would have been logical, relevant and cost-effective. However, it has not been even discussed on formal level due to the fragmented position of the European states and the inability to come up with a unified position.

\section{Is the Berlin Plus Agreement still relevant?}

After the Libyan crisis, the relevance of the Berlin Plus Arrangement has been questioned again. The agreement has not been re-activated since December 2004, while the necessity of burden sharing between the institutions in this complex world is visible.

To the largest extent, Berlin Plus as a cooperation format has been designed for the Balkans. European countries felt threatened and vulnerable due to the instability at their doorsteps. From NATO and the US perspective, the Agreement was a convenient opportunity to retain a footprint on the Balkans and be involved in the ongoing operation through SHAPE.

Long discussions on further activation of the Agreement have been taking place throughout the years, but without concrete delivery. Even more so, in

94 Koutrakos, The EU Common Security and Defense Policy, 131.

95 Peters, ed., The European Union and the Arab Spring, 42.

96 Ibid.

97 Ibid. 
2005 the notion of the "Berlin Plus in Reverse" ${ }^{98}$ was promoted, which implied utilization of the EU civilian assets and capabilities by NATO in crisis management operations. However, decision has not been reached due to the different positions among the EU members.

Hence, the Berlin Plus agreement has not been reapplied for two reasons: internal and external. As it was mentioned, the Berlin plus allows NATO-EU cooperation only in the military domain and under the conditions when the one of the organizations officially requests its activation. Hereby, the unity of the European states is decisive. As the case studies on Libya and Afghanistan showed, EU members' positions are fragmented and nationally driven when it comes to the foreign and security policy. Therefore, the internal challenges of the CSDP decrease the possibility of further implementation of the agreement. On external level, even if the EU comes with a united position, the activation of the agreement can be hampered by the non-dual member states such as Turkey and Cyprus and impeded by the lack of common strategic vision among institutions.

To conclude, the Berlin Plus agreement, representing the only institutional framework between the organizations, exists as a tool, but not as an effective instrument to be further utilized. From an operational point of view, it is still relevant (ongoing operation "Althea" in Bosnia-Herzegovina). From legal perspective, the agreement is in place and can be activated once decided. But from political and strategic angle it suffers serious problems and remains as a façade rather than efficient mechanism.

\section{Conclusion}

Contemporary security threats and challenges necessitate and naturally push NATO-EU relations towards more effective cooperation. With the largest membership of the Western Community, complementary capabilities and common agenda they can efficiently contribute to maintaining peace and stability throughout the world. Thorough analysis of the factors limiting an effective cooperation among institutions will help policy makers to better address those challenges.

The article examined the impact of the dual and non-dual member states on shaping organizations' interaction and identified key millstones in existing strategic, political and legal framework of cooperation.

The article focused on Turkey and Cyprus from the non-dual members, and analyzed to what extent the dual members influence the interaction between the organizations in the cases of Libya and Afghanistan.

According to the case studies analysis following findings can be formulated.

98 Erwan Lagadec, Transatlantic Relations in the 21 Century: Europe, America and the Rise of the Rest (New York: Routledge, 2012), 120, 121. 
Some of the non-dual member countries "hold institutions hostage" ${ }^{99}$ due to their national interests; Turkey and Cyprus, having a political dispute between them, are using "veto power" and contribute to the limited cooperation to a certain extent.

Divergent position of the dual member states with regard to the CSDP is translated into the lack of a NATO-EU joint strategic vision. ${ }^{100}$ Hence, the fragmented position of the European states within CSDP serves as the root cause of the limited cooperation among organizations. In reality, dual members even do not strive to develop a unified, holistic and a clear EU policy on crisis management and are comfortable with the existing uncertainty among the institutions because they do not want to limit the flexibility in utilizing the organizations capabilities according to their preferences.

The case studies of Libya and Afghanistan clearly revealed that whether threat is imminent or not, at the doorsteps of Europe or beyond its borders, cooperation is required in military or non-combatant direction, organizations' interaction is not very successful. The EU and NATO deal with the concrete crisis situations on a case by case basis without having a common strategic approach.

Absence of division of labor among the institutions leads to the duplication of functions to a certain extent. Overlap in the functions between institutions is derived from exogenous and endogenous factors: current crisis management situations require utilization of the civilian and military capabilities simultaneously; internally, due to the lack of division of labor, organizations strive to develop additional capabilities (EU - military; NATO - civilian) resulting in duplication.

The Berlin Plus Agreement is still relevant on legal and operational level but outdated on the strategic-political level. Cooperation among institutions is better in the theater of operation rather than on the strategic level.

Based on the results of analysis, it can be argued that EU and NATO can transform their relations into more fruitful and mutually beneficial cooperation if they address the following areas: the EU should elaborate more clear guidance or policy on CSDP concentrating on two key directions: (1). Definition of the area and conditions under which CSDP operation/missions are activated; (2). Provision of sufficient human and logistic capabilities in a timely and rational manner. Furthermore, the EU should enhance the coordination among its structures to smoothly implement assigned tasks and objectives; strive to develop cooperation framework with NATO beyond the Berlin Plus agreement, which inherently limits itself to the military collaboration. Both institutions should mobilize efforts leading to the resolution of the Cyprus issue in a way acceptable to Turkey and Cyprus (Greece) and contribute to the elaboration of a joint EU-NATO strategic vision with clear division of responsibilities.

99 Howorth, Security and Defence Policy in the European Union, 130.

${ }^{100}$ UK's vote to leave European Union is again a clear demonstration of the fragmented position of the European states. 
Hence, there is a high need for burden sharing between the EU and NATO in the existing complex security landscape. Furthermore, the potential of two institutions to contribute to crisis management in more effective and efficient ways is also present and vital. Therefore, for the sake of peace and stability "the EU and NATO should and can play complementary and reinforcing roles." 101

\section{ANNEX A}

\section{2 members in common}

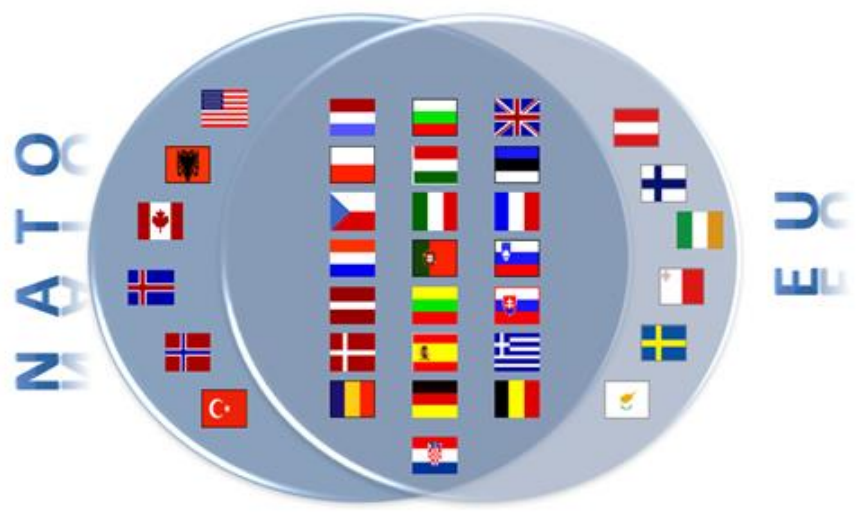

Members of NATO and not EU: Albania, Canada, Iceland, Norway, Turkey, USA.

Members of EU and not NATO: Austria, Cyprus, Finland, Ireland, Malta, Sweden. $^{102}$

Dual members: Belgium, Bulgaria, Croatia, Czech Republic, Denmark, ${ }^{103}$ Estonia, France, Germany, Greece, Hungary, Italy, Latvia, Lithuania, Luxembourg, Netherlands, Poland, Portugal, Romania, Slovakia, Slovenia, Spain, UK.

${ }^{101}$ NATO, "Active Engagement, Modern Defence - Strategic Concept for the Defence and Security of the Members of the North Atlantic Treaty Organization," accessed April 11, 2016, http://www.nato.int/strategic-concept/pdf/Strat_Concept_web_ en.pdf.

102 Denmark opted out of ESDP; Stephanie C. Hofmann, "Overlapping Institutions in the Realm of International Security: The Case of NATO and ESDP," Perspectives on Politics 7, no. 1 (March 2009): 45-52.

${ }^{103}$ Hofmann, "Overlapping Institutions in the Realm of International Security." 


\section{About the author}

Ms. Tinatin Aghniashvili has an extensive professional experience in defense and security matters. Since 2007 she has been occupying various positions within the International Relations and Euro-Atlantic Integration Department of the Ministry of Defense of Georgia. From 2013 she leads the NATO Integration Division and largely contributes to successful NATO-Georgia cooperation. Ms. Aghniashvili received a BA degree in International Relations in 2005, a Master degree in International Relations from Tbilisi State University in 2007, and a Master of Advance Studies in International and European Security from the University of Geneva in 2016. Ms. Aghniashvili attended defense and security related long-term courses at Tartu University, George C. Marshall European Center for Security Studies and Geneva Center for Security Policy. Ms. Aghniashvili lectures at state and private universities on different subjects related to international affairs. She is fluent in English and Russian.

E-mail: taghniashvili@mod.gov.ge. 